Canadian Journal of Bioethics

ICB B

Revue canadienne de bioéthique

\title{
A Response to Nico Nortjé's Review of The Moral Work of Nursing
}

Hazel Magnussen

Volume 2, Number 2, 2019

URI: https://id.erudit.org/iderudit/1060914ar

DOI: https://doi.org/10.7202/1060914ar

See table of contents

Publisher(s)

Programmes de bioéthique, École de santé publique de l'Université de Montréal

ISSN

2561-4665 (digital)

Explore this journal

Cite this document

Magnussen, H. (2019). A Response to Nico Nortjé's Review of The Moral Work of Nursing. Canadian Journal of Bioethics / Revue canadienne de bioéthique, 2(2),

51-51. https://doi.org/10.7202/1060914ar

All Rights Reserved (c) Hazel Magnussen, 2019

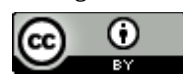

This document is protected by copyright law. Use of the services of Érudit (including reproduction) is subject to its terms and conditions, which can be viewed online.

https://apropos.erudit.org/en/users/policy-on-use/ 
LETTRE À L’ÉDITEUR / LETTER TO THE EDITOR

\title{
A Response to Nico Nortjé's Review of The Moral Work of Nursing
}

\author{
Hazel Magnussen ${ }^{1}$
}

Texte discuté/Text discussed: Nortjé N. Review of: Magnussen H. (2017) The Moral Work of Nursing - Asking and Living with the Questions. Can J Bioeth/Rev Can Bioeth. 2019;2(2):15-16

Mots-clés

éthique infirmière, éthique des soins de santé

\author{
Keywords \\ nursing ethics, healthcare ethics
}

I am writing in response to Nico Nortje's review of my book, The Moral Work of Nursing: Asking and Living with the Questions [1], which was published in the March issue of this journal [2]. The reviewer effectively summarizes four themes in the book: "practical application and approach to nursing knowledge; the institutional challenges faced by nurses; the political reforms affecting the profession, and the social and technological problems that could create challenges for nurses." Suggesting that the book makes a contribution to global ethics, he refers to my accounts of northern nursing early in my career and recognition of vestiges of colonialism in Canadian healthcare. Reviews of current research regarding the moral nature of nurses' work in the broader context of healthcare, such as public health and home health in chapters 9 and 10 , receive little attention.

The review highlights the section on burnout and workplace violence and bullying, which are discussed in chapters 12 and 13 on Nurses' Health and Psychological Health and Safety in the Healthcare Workplace. These are sensitive matters that may be perceived differently by readers, depending on their experience and understanding of the issues. The review states: "the book's frank discussion about workplace abuse (emotional, physical and sexual) stands out, drawing the attention of the reader to the fact that nurses are victims and arguing that there needs to be a collective stand against abuse and bullying." I am uncomfortable with this interpretation. I do not make reference to sexual abuse in the book, nor do I refer to nurses as victims. I note that nurses may be targets of abuse; but I deliberately try to avoid the word "victim" since for many, it implies powerlessness. In fairness, the review does include my call for a collective stand against abuse and bullying.

Perhaps the reviewer is referring to the fact that much of the moral work of nursing is related to the imbalance of power in the system as reviewed in chapter 5 on Power in Physician Nurse Relationship and in chapter 7 on Moral Distress in Nursing. From that power perspective, the moral work of nurses involves advocacy that requires moral courage when exercising moral agency. My goal in writing the book, The Moral Work of Nursing, was to validate and encourage nurses in their work; and to raise awareness of other readers of the uniqueness of the nursing experience and responsibilities in promoting safe and ethical healthcare for all.

Conflits d'intérêts

Je suis l'auteure de The Moral Work of Nursing, Asking and Living with I am the author of The Moral Work of Nursing, Asking and Living with the Questions.

Édition/Editors: Bryn Williams-Jones

Affiliations

${ }^{1}$ Edmonton, Canada

Correspondance / Correspondence: Hazel Magnussen, authorhazel@gmail.com

Reçu/Received: 1 May 2019

Publié/Published: 6 May 2019

Les éditeurs suivent les recommandations et les procédures décrites dans le Code of Conduct and Best Practice Guidelines for Journal Editors de COPE. Plus précisément, ils travaillent pour s'assurer des plus hautes normes éthiques de la publication, y compris l'identification et la gestion des conflits d'intérêts (pour les éditeurs et pour les auteurs), la juste évaluation des manuscrits et la publication de manuscrits qui répondent aux normes d'excellence de la revue.
The editors follow the recommendations and procedures outlined in the COPE Code of Conduct and Best Practice Guidelines for Journal Editors. Specifically, the editors will work to ensure the highest ethical standards of publication, including: the identification and management of conflicts of interest (for editors and for authors), the fair evaluation of manuscripts, and the publication of manuscripts that meet the journal's standards of excellence.

\section{References}

1. Magnussen $\mathrm{H}$. The Moral Work of Nursing - Asking and Living with the Questions ( $2^{\text {nd }}$ ed.) Promontory Press; 2017.

2. Nortjé N. Review of: Magnussen H. (2017) The Moral Work of Nursing - Asking and Living with the Questions. Canadian Journal of Bioethics/Revue canadienne de bioéthique. 2019;2(2):15-16 